DOI 10.18551/rjoas.2021-10.35

\title{
SWAMP FISHING RESOURCES MANAGEMENT: AN ECONOMIC APPROACH TO HARUAN FISHING (CHANNA STRIATA)
}

\author{
Sofia Leila A. ${ }^{*}$, Agusliani Erma, Hidayat Achmad Syamsu \\ Study Program of Fisheries Socio-Economics, Faculty of Fisheries and Marine Science, \\ University of Lambung Mangkurat, South Kalimantan, Indonesia \\ *E-mail: syamsu@ulm.ac.id
}

\begin{abstract}
Haruan fish (Channa striata) is one type of inland fish that has production potential and important economic value, as well as being a source of food for some people in Asia. The purpose of this study was to assess the financial viability of the snakehead fishing business and to determine the factors that influence the production of haruan fishing. The research was conducted using a survey method in Martapura Barat Subdistrict, Sungai Tabuk Subdistrict, with the consideration that the area has swamp waters which are the main habitat of haruan fish which is quite extensive and is a center for capture fisheries of swamp waters in Banjar Regency. The sample of fishermen was taken as many as 70 fishermen, consisting of 44 banjur fishing fishermen and 26 pair fishing fishermen. The data collected were analyzed descriptively and quantitatively with a multiple linear regression model approach. The results of the analysis show that catching Haruan fish with fishing rods is financially profitable so it is feasible for expansion of application. Meanwhile, fishing with banjur fishing rods can provide a higher profit value than pair fishing, which reaches Rp. $12,021,993$,- per year. The production factors that have a positive effect on the production of haruan fish are operational capital, the number of fishing gear operated, the number of fishing trips, and the type of fishing line used. Meanwhile, the length of time of capture actually has a negative effect on production (catch). Efforts to increase the production of Haruan fish catch can still be done by increasing operational capital, the number of fishing gear operated, and the use of more effective types of fishing rods such as banjur, as well as increasing the number of fishing trips, but it is necessary to allocate effective fishing gear operational time so that the catch can be achieved.
\end{abstract}

\section{KEY WORDS}

Economics, fisheries, swamps, business finance, management.

The production of fish caught in inland waters reaches 11.6 million tons or 12.8 percent of the total global capture fisheries production (FAO, 2018). These fisheries have become a source of livelihood for millions of the world's population and food for billions of other people (Lynch, et al., 2016). Capture fisheries in inland waters are mainly developed traditionally by most small-scale fishing households, both as a source of family protein, cash income, as well as trade and business (Kasthala, et al., 2008). One of the potential commodities for inland fisheries is snakehead snakehead fish (Channa striata). This carnivorous fish is found naturally in freshwater sources that cross a number of countries in Southeast Asia and is most widely distributed among members of other snakehead species (Laxmappa, 2017); (Enomoto et al., 2011); (Robert, Amit, Sukarno, Majapun, \& Kumar, 2019). This fish is very tolerant of various environmental conditions; its movement and adaptation was very fast towards the new colony (Tan, Jamsari, \& Siti Azizah, 2012), until it spread in Indonesia covering Java, Kalimantan, Sulawesi, Sumatra, Bangka, Madura, Bali, Lombok, Flores, Ambon, and Halmahera. . Some of the traditional fishing gear used to catch Haruan fish are fishing rods, beje (Sofia, 2017), gill nets, nets, traps, and others. Snakehead is an important commercial fish in Thailand, Philippines, Cambodia and Vietnam, as well as in some parts of Indonesia.

The demand for haruan fish in fresh (live) form is quite high so the selling price is quite high (Sofia \& Nurlianti, 2019). In recent years, the demand for haruan fish has increased 
because several research results show that haruan fish meat is very rich in albumin type protein which is very useful for accelerating wound healing and a source of medicinal ingredients (Ndobe, Serdiati, \& Moore, 2014); (Haniffa, Jeya Sheela, Kavitha, \& Jais, 2014); (Kadir, 2018). Various fishing practices must be carried out to spur increased catches, even the use of fishing methods prohibited in government regulations, such as catching brood fish, using electric fishing gear, using chemicals, and catching young fish.

However, fishing activitiesof the demand for haruan fish in fresh (live) form is quite high so that it has a positive impact on the selling price (Sofia \& Nurlianti, 2019). This condition is one of the driving forces for the increase in the practice of "quick yielding production" for wild fish resources, such as catching brood fish, juveniles, using electric fishing gear, and catching using toxic chemicals. Increased human activity destroys feeding grounds and fish hatcheries, leading to a decrease in wild catches (Muntaziana, Amin, Aminur Rah, Rahim, \& Marimuthu, 2013). In recent years, haruan fish are increasingly being hunted because the meat of haruan fish is very rich in albumin type protein so it is very useful for accelerating wound healing and a source of medicinal ingredients (Ndobe, Serdiati, \& Moore, 2014); (Haniffa, Jeya Sheela, Kavitha, \& Jais, 2014); (Kadir, 2018). However, intensive hunting has led to a downward trend in fish production in the last decade, as it is predicted that more than $10 \%$ of the global population is facing a decline in micronutrients and fatty acids (Golden, 2016). Likewise, the production of haruan fish is one of a number of freshwater fish species in Kalimantan that are threatened with extinction. For example, the production of haruan fish in Banjar Regency, South Kalimantan, which decreased during the 2012-2016 period, from $569.2 \mathrm{~kg}$ to $442.6 \mathrm{~kg}$. Meanwhile, the level of consumer demand for haruan fish does not match the availability (production) causing the price of haruan fish to increase from IDR 37,000 per $\mathrm{kg}$ in 2012 to IDR 62,000 per kg (Department of Marine and Fisheries of South Kalimantan Province, 2017)

Economically, the symptoms of declining productivity should be a warning or sign for fishermen to leave the industry. When this happens, overfishing (biological overfishing) occurs together with excess investment (economic overfishing) (BALIRWA et al., 2003); (Muhammad, lqbal, \& Saleemi, 2016). Fishing efforts must have a good understanding of current uses, limitations on destructive fishing models (Manzi \& Coomes, 2002); (Chen, Li, \& Wang, 2012), and the development of small-scale fisheries by prioritizing local and affordable technologies (Barkhuizen, Weyl, \& van As, 2016)

Therefore, it is important to reduce the decrease in fishing efforts that are not environmentally friendly by developing selective and environmentally friendly fishing gear, as well as locally based types of fishing rods. The purpose of this study is to assess the financial feasibility offishing rods and determine the factors that affect their production.

\section{MATERIALS AND METHODS OF RESEARCH}

Description of the study sites. The research was conducted using a survey method at a deliberately designated location, namely the District of West Martapura covering the Village of Keliling Benteng Ulu, Village of Keliling Benteng Tengah, and Village of Antasan Sutun; and Sungai Tabuk Sub-district covering Benteng Ilir Mobile Village, Lok Baintan Village, and Sungai Bangkal Village. The study sites were chosen with the consideration that all of these areas have large enough swampy waters as the main habitat for haruan fish and are centers of capture fisheries in Banjar Regency (Figure 1). Primary data collection was carried out in July - September 2018.

Population and samples. The population of the study was haruan fisherman (Channa sriata) with banjur fishing gear and pair fishing rods as many as 236 RTP (Banjar District Fisheries Service, 2018). Then 70 fishermen were taken as a simple random sample including 44 banjur fishing fishermen and 26 pair fishing fishermen.

Data analysis. Data analysis was carried out descriptively based on the tabulation results of the costs and benefits generated. 


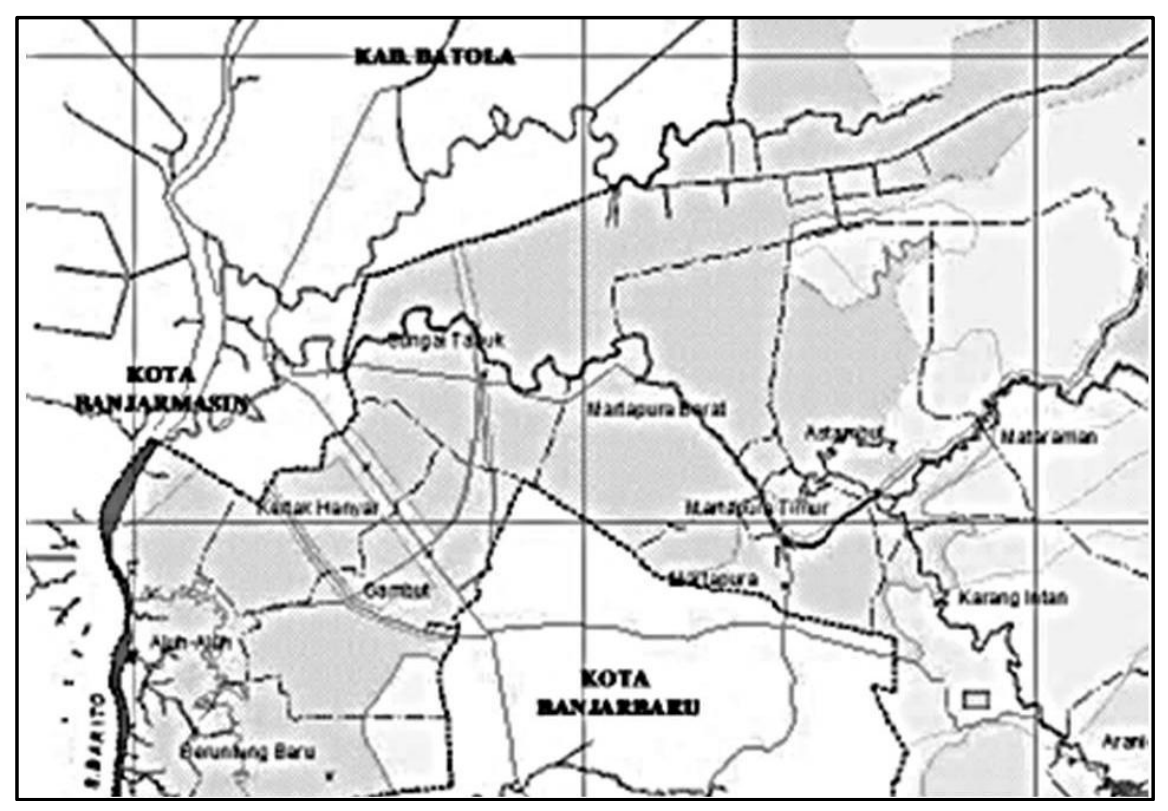

Figure 1 - Research Location

Business feasibility analysis according to short-term investment criteria:

Profit analysis $\pi=\mathrm{TR}-\mathrm{TC}$

Where: $\pi=$ operating profit; $\mathrm{TR}=$ total receipts; $\mathrm{TC}=$ total cost.

Decision criteria:

- $\quad T R<T C$, then the business loses (no profit);

- $\mathrm{TR}=\mathrm{TC}$, then the business breaks even (no profit and no loss);

- $\mathrm{TR}>\mathrm{TC}$, then the business is profitable.

$$
R / C \text { Ratio }=\frac{\text { Total receipts }}{\text { Total fixed costs }+ \text { Total variable costs }}
$$

Decision criteria:

- $\mathrm{R} / \mathrm{C}<1$, then the business is relatively unprofitable;

- $\mathrm{R} / \mathrm{C}=1$, then the business breaks even;

- $\mathrm{R} / \mathrm{C}>1$, then the business is relatively profitable;

$$
\begin{gathered}
\text { Break-even point } \mathrm{BEP}_{\text {Production }}=\frac{\text { Total Cost }}{\text { Sales Price }} \\
\mathrm{BEP}_{\text {price }}=\frac{\text { Total cost }}{\text { Total production }}
\end{gathered}
$$

Decision criteria:

- $B E P_{\text {production }}>$ the number of units produced at this time, then the business is feasible to run;

- $B E P_{\text {price }}<$ current product price, then the business is worth running.

$$
\text { Payback Period }(\mathrm{PP})=\frac{\text { Total investment }}{\text { profit }} \times 1 \text { year }
$$

Determination of the factors that influence the production of haruan catches is estimated by using multiple linear regression models using the Ordinary Least Square (OLS) method (Gujarati, 2004). The multiple linear regression models compiled are: 


$$
Y=\alpha+\beta_{1} X_{1}+\beta_{2} X_{2}+\beta_{3} X_{3}+\beta_{4} X_{4}+\beta_{5} X_{5}+\beta_{6} X_{6}+D+e
$$

Where:

Y: Production (catch) of Haruan fish (kg/year);

$\mathrm{b}_{0}$ : Intercept; b1 - b6: regression coefficient;

$\mathrm{X}_{1}$ : Operational capital (Rp/year);

$\mathrm{X}_{2}$ : Number of fishing trips (times/year);

$\mathrm{X}_{3}$ : Number of fishing gear (unit/year);

$\mathrm{X}_{4}$ : Distance from fishing ground $(\mathrm{km})$;

$\mathrm{X}_{5}$ : Capture time (settings);

$X_{6:}$ Number of bait (tail);

$D$ : Type of fishing gear (dummy variable);

$0=$ pair fishing gear;

$1=$ banjur fishing gear.

\section{RESULTS AND DISCUSSION}

Haruan fish in South Kalimantan are found in almost all types of public waters (monotonous swamps, tidal swamps, small rivers and reservoirs). The habitat of this fish is in wetlands and small rivers, lakes and swamps (Wisdom, 2004). This type of habitat is used as a fishing ground for haruan fish by fishermen in the vicinity. The early season of haruan fishing can be seen from the fishing activities that are starting to appear, even though the catch is still small. The early fishing season usually occurs around January - February. The peak season for harpoon fishing, which is quite abundant catches, usually occurs in MarchJuly. Meanwhile, the famine season for haruan occurs around August - January, where the consumption size of haruan fish is very small and haruan fish enter the spawning period.

Generally, the fishing gear that is often used by fishermen with the main target of haruan fish are banjur fishing rods and pair fishing rods. Banjur fishing line is a type of fishing rod with a short rod about 1 meter long made of small diameter bamboo or other floating materials, and equipped with ropes, hooks, and bait. The operation of this fishing line is that the hooks that have been baited are placed in potential places and after that they are left, usually left overnight, and taken back when there is already a fish caught. The number of banjur fishing rods installed in one operation is usually quite a lot (50-100 rods). While the pair fishing is a fishing rod with a rod length of about 8-10 meters. The operation of this fishing line is that the hook that has been fed with splash bait (medium-sized frog) is thrown as far as possible first, then moved like a frog swimming.

The production of the catch and the number of trips (operational) for harpoon fishing according to the type of fishing line used by fishermen in the study locations were quite varied. The volume of production of haruan fish using banjur fishing rods is higher than the catch of fishermen using paired fishing rods. This is mainly due to the fact that the number of banjur fishing rods operated in each trip is much higher (50-100 units) than the pairfishing rods which are only 1 unit so that the opportunity to get more catches is greater.

Table 1 - Haruan fish (Channa striata) production by type of fishing line

\begin{tabular}{llllllll}
\hline \multirow{2}{*}{ No. } & \multirow{3}{*}{ Description } & \multicolumn{3}{l}{ Gear type } \\
\cline { 3 - 7 } & & \multicolumn{2}{l}{ Banjur fishing } & \multicolumn{3}{l}{ Pair fishing } \\
\cline { 3 - 7 } & & Max & Min & Average & Max & Min & Average \\
\hline 1. & Production per trip(kg) & 10 & 3 & 6.23 & 3 & 1.5 & 2.13 \\
2. & Production per year(kg) & 1.680 & 216 & 836.69 & 300 & 108 & 230 \\
3. & Catching trip(times/year) & 168 & 72 & 133 & 144 & 72 & 110 \\
\hline
\end{tabular}

Fishing business with banjur and pair fishing requires a number of operational costs in each fishing effort, but the costs required are not too large with an average operational cost of Rp 102,216 per trip and Rp 42,333.33 per trip. The operational costs of catching haruan fish with fishing rods consist of fishing rods, nylon rope, fishing rods and bait, as well as 
fishermen's provisions during the operation of fishing gear. The average operating cost per year for banjur fishing rods reaches Rp. 13,654,800 and is much higher than the average operating cost for fishing pairs which is only Rp. 4,630,000 (Table 2). This is possible in addition to more banjur fishing trips in one year than pair fishing, the number of banjur fishing rods used in one fishing trip is also more and fishing rods are usually only used once in one trip; while the fishing pair can still be used $>3$ times catching trips.

Table 2 - Production costs and revenue for haruan fishing (C. striata) by type of fishing line

\begin{tabular}{|c|c|c|c|c|c|c|c|}
\hline \multirow{3}{*}{ No. } & \multirow{3}{*}{ Description } & \multicolumn{6}{|c|}{ Gear type } \\
\hline & & \multicolumn{3}{|c|}{ Banjur fishing } & \multicolumn{3}{|c|}{ Pair fishing } \\
\hline & & Max & Min & Average & $\operatorname{Max}$ & Min & Average \\
\hline \multirow[t]{3}{*}{1.} & operating costs & & & & & & \\
\hline & per trip (Rp 000) & 232.50 & 44.05 & 102.22 & 49 & & 42.33 \\
\hline & per year (Rp 000) & 39,060 & $3,207.6$ & $13,654.80$ & 6,624 & 3,168 & 4,630 \\
\hline 2. & price of haruan fish $(\mathrm{Rp} 000 / \mathrm{kg})$ & 38 & 20 & 30.47 & 36 & 33 & 34.25 \\
\hline \multirow[t]{3}{*}{3.} & reception: & & & & & & \\
\hline & per trip (Rp 000) & 350 & 75 & 190.56 & 99 & 49.50 & 72.42 \\
\hline & per year (Rp 000) & 58,800 & 6,480 & $25,676.79$ & 10,500 & 3,780 & 7,861 \\
\hline \multirow[t]{3}{*}{4.} & profit: & & & & & & \\
\hline & per trip (Rp 000) & 117.5 & 30.95 & 88.34 & 50 & 11.5 & 30.08 \\
\hline & per year (Rp 000) & 34,104 & 1,368 & $12,021.99$ & 5,340 & 612 & 3,231 \\
\hline
\end{tabular}

The results of the business financial feasibility analysis show that haruan fishing business using both banjur fishing gear and pair fishing rods has a ratio between revenue and costs that is greater than 1 (Table 3) so that both types of fishing business are feasible to continue. Meanwhile, the length of return on investment for both types of fishing rods is included in the fast category because the average payback period is under 5 years. This is possible because the business capital for both types of fishing rods is relatively small and each investment item used is classified as non-durable good with an economic life of less than 1 year, so the cost of capital goods for fishing business tends to be variable.

The results of the analysis of the production volume limit of a business reaching the break-even point (BEP) shows that the current average production volume of fish caught with banjur fishing rods is $836.69 \mathrm{~kg}$ per year which still exceeds the break-even limit of production volume $(448.08 \mathrm{~kg})$. per year); Likewise, the average volume of haruan catches with paired fishing rods as much as $230 \mathrm{~kg}$ per year still exceeds the production volume at the break-even limit (135.18 kg per year). Meanwhile, the production value limit (price) of haruan fish in the current (actual) condition with banjur and pair fishing rods is Rp. 30,474.14 per $\mathrm{kg}$ and $\mathrm{Rp} .34,250$ per $\mathrm{kg}$, respectively; where these prices still exceed the break-even limit, the average price of fresh haruan fish is Rp. 16,320.03 per $\mathrm{kg}$ and Rp. 20,130.43 per $\mathrm{kg}$.

Table 3 - Financial feasibility of haruan fishing (C. striata) by type of fishing line

\begin{tabular}{llll}
\hline \multirow{2}{*}{ No. } & \multirow{2}{*}{ Description } & Gear type & Pair fishing \\
\cline { 3 - 4 } & Revenue Cost Ratio (RCR) & Banjur fishing & 1.70 \\
2 & Payback Period (PP) & 1.88 & 1.43 \\
3 & Break Event Point (BEP): & & \\
& Production & 448.08 & 135.18 \\
& Price & $16,320.03$ & $20,130.43$ \\
\hline
\end{tabular}

The results of linear regression analysis resulted in a coefficient of determination (R2) of 0.8531 or $85.31 \%$ of the variation in the production of haruan fish that could be explained by the variables included in the model, while the remaining $14.69 \%$ was explained by the variables (factor others) outside the model. The results of the test of the effect of all independent variables on the dependent variable resulted in an Fcount of 51.4524 with a significance value of $>95 \%$. This means that all variables included in the model together have a very real influence on the production of wild fish. While the results of the partial test ( $t$ 
test) showed that the variables of operational capital, number of trips, number of fishing gear operated, and the type of fishing gear used had a positive and very significant effect (significant $>95 \%$ ) on the production of haruan catches. However, the catch time variable has a negative and very significant effect on the production of haruan fish catches (Table 4).

Table 4 - Factors affecting the production of haruan fish (C. striata)

\begin{tabular}{|c|c|c|c|c|}
\hline \multirow{2}{*}{ Variable } & \multicolumn{2}{|c|}{ Unstandardized Coefficients } & \multirow{2}{*}{$t$-stat } & \multirow{2}{*}{$P$-value } \\
\hline & $\beta$ & Std. Error & & \\
\hline Intercept & -788.302 & 117.733 & -6.6957 & 7.21E-09 \\
\hline operating capital & $0.0028^{* *}$ & 0.0005 & 5.5569 & $6.15 \mathrm{E}-07$ \\
\hline number of trips & $6.2855^{\star *}$ & 0.7020 & 8.9540 & 8.91E-13 \\
\hline number of fishing gear & $0.0285^{\star \star}$ & 0.0127 & 2.2513 & 0.027923 \\
\hline catch area & 23.2261 & 48.3945 & 0.4799 & 0.632964 \\
\hline operational time & $-23.1174^{\star \star}$ & 8.3772 & -2.7596 & 0.0076 \\
\hline number of feeds & 0.0004 & 0.0030 & 0.1339 & 0.8939 \\
\hline type of fishing line(dummy) & $490.0053^{\star *}$ & 100.2728 & 4.8867 & 7.57E-06 \\
\hline
\end{tabular}

The traditional snakehead fishing business does not require large operational capital, where the operational capital requirements for each catch are only around IDR 44.05 232.50 (banjur fishing line) and IDR 38 - 49 (fishing pair). These operational costs consist of the cost of providing fishing equipment and few supplies, no transportation and labor costs because the fishing location is quite close to the village and is done by yourself. In line with (Loeung, Schmidt-Vogt, \& Shivakoti, 2015), input costs for family-scale fishing are mainly for the purchase of nets (gillnets, cast nets) and hooks (fishing rods). There are no fees at the fishing grounds, no labor or transportation costs. The results of the analysis show that the relationship between the amount of operational capital and the fishing results is positive (Table 4) so that additional operational capital will spur an increase in snakehead fish production.

The fishing operation time has a significant negative effect on the catch of wild fish, meaning that if the number of hours of fishing is increased, there will be a large decrease in production. This is different from the results of Sudirman (2013) which states that the number of hours of operation in catching tuna with a hand line has a positive effect on catches. This can be explained based on the nature of the type of fishing line used. Tuna fishing rods are more active following the nature of groups of tuna fish that move actively. Meanwhile, the haruan fish are not very active and not in groups but are individual so that the fishing rods used tend to be waiting. Usually haruan fishing rods that have been baited are left for a few hours before being picked up again. The fishing rods that are stocked become less controlled because they are left too long so there is the potential for the bait to be lost by fish or other aquatic animals that are not the target of catching or haruan fish that have been caught loose. This is corroborated by the opinion (Monk \& Arlinghaus, 2017) that the length of operational time has the potential to increase encounters which in turn should encourage the vulnerability of fish to be caught by passively operated tools. However, he found no evidence of a significant relationship between various encounter-based behaviors and susceptibility to fishing. Therefore, in order to achieve optimal production, it is necessary to have a long operational time for effective haruan fishing.

The results of the analysis showed that the regression coefficient value for the number of fishing trips had a significant positive effect on the production of haruan fish. Thus, the greater the number of fishing trips, the more production of haruan fish will be produced. The results of this analysis agree with the results of Sahido's research (2016); Retnowati, et al (2017) that the number of fishing trips has a significant positive effect on the catch of fishing rods.

The number of fishing rods operated on each trip has a positive effect on snakehead fish production. For the purpose of conservation of fish resources, it is necessary to apply fishing gear that is able to reduce encounters with non-target fish (Raby, Colotelo, BlouinDemers, \& Cooke, 2011). Fishing gear is one of the recommended selective fishing gear. 
Thus, it is highly recommended to increase the number of fishing gear to increase snakehead fish production. Meanwhile, the type of fishing gear used also has a different positive effect on the catch. It was proven that catching haruan with banjur fishing rods gave higher catches than those with paired fishing rods. This is closely related to the number of fishing rods that are operated, for banjur fishing rods in one trip, 50-100 fishing rods are operated while fishing pairs in one trip only operate one fishing line unit.

\section{CONCLUSION}

Fishing with fishing rods is financially profitable so it is feasible for expansion of application. Meanwhile, fishing with banjur fishing rods can provide a higher profit value than pair fishing, which reaches Rp. 12,021,993,- per year. The production factors that have a positive effect on the production of haruan fish are operational capital, the number of fishing gear operated, the number of fishing trips, and the type of fishing line used. Meanwhile, the length of time of capture actually has a negative effect on production (catch). Efforts to increase the production of Haruan fish catch can still be done by increasing operational capital, the number of fishing gear operated, and the use of more effective types of fishing rods such as banjur, as well as increasing the number of fishing trips, but it is necessary to allocate effective fishing gear operational time so that the catch can be achievedoptimized.

\section{ACKNOWLEDGMENTS}

We express our deepest gratitude to the Postgraduate Program at Lambung Mangkurat University as the funder of the research (SKP No. 197/UN8.4/KU/2018 dated July 2, 2018), village heads and haruan fishing fishermen in the study area. has been willing to cooperate and provide the information we need.

\section{REFERENCES}

1. Balirwa, J. S., Chapman, C. A., Chapman, L. J., Cowx, I. G., Geheb, K., Kaufman, L., ... Witte, F. (2003). Biodiversity and Fishery Sustainability in the Lake Victoria Basin: An Unexpected Marriage? BioScience, 53(8), 703. https://doi.org/10.1641/00063568(2003)053[0703:bafsit]2.0.co;2.

2. Barkhuizen, L. M., Weyl, O. L. F., \& van As, J. G. (2016). A qualitative and quantitative analysis of historic commercial fisheries in the Free State Province in South Africa. Water SA, 42(4), 601-605. https://doi.org/10.4314/wsa.v42i4.10.

3. Gujarati, D.N (1988). Basic Econometrics. McGraw-Hill. pp. 705.

4. Bijaksana U. (2006). Preliminary studies reproductive bio-eco snakehead in the swamp Bangkau South Kalimantan Province. National Symposium of Biotechnology in Aquaculture 2006. Department of Aquaculture Faculty of Fisheries and Marine Sciences Bogor Agricultural University and Research Institute of Fisheries Freshwater Aquaculture Marine and Fisheries Research Agency. 5 Juli 2006. [in Indonesian].

5. Chen, D., Li, S., \& Wang, K. (2012). Enhancement and conservation of inland fisheries resources in China. Environmental Biology of Fishes, Vol. 93, pp. 531-545. https://doi.org/10.1007/s10641-011-9948-2.

6. Enomoto, K., Ishikawa, S., Hori, M., Sitha, H., Song, S. L., Thuok, N., \& Kurokura, H. (2011). Data mining and stock assessment of fisheries resources in Tonle Sap Lake, Cambodia. Fisheries Science, 77(5), 713-722. https://doi.org/10.1007/s12562-011-0378z.

7. Golden, C. D., Allison, E. H., Dey, M. M., Halpern, B. S., McCauley Douglas J., Smith Matthew, \& Vaitla, B. (2016). Fall in Fish Catch Threatens Human Health. Nature, 534, 317-320.

8. Haniffa, M. A. K., Jeya Sheela, P. A., Kavitha, K., \& Jais, A. M. M. (2014). Salutary value of haruan, the striped snakehead Channa striatus - A review. Asian Pacific Journal of Tropical Biomedicine, 4(Suppl 1), S8-S15. https://doi.org/10.12980/APJTB.4.2014C1015 
9. Kadir, A. A. (2018). Snakehead Fish (Channa Striatus) in the Management of Osteoarthritis: Clinical Research and Possible Mechanism of Action. Chinese Journal of Traditional Medicine, 1(1), 1-7. Retrieved from https://www.researchgate.net/publication/330554391.

10. Laxmappa, B. (2017). A view on murrel ( snakeheads ) fi sheries in India. 22(3), 15-19.

11. Loeung, K., Schmidt-Vogt, D., \& Shivakoti, G. P. (2015). Economic value of wild aquatic resources in the Ang Trapeang Thmor Sarus Crane Reserve, North-western Cambodia. Wetlands Ecology and Management, 23(3), 467-480. https://doi.org/10.1007/s11273014-9395-x.

12. Lynch, A. J., Cooke, S. J., Deines, A. M., Bower, S. D., Bunnell, D. B., Cowx, I. G., ... Beard, T. D. (2016). The social, economic, and environmental importance of inland fish and fisheries. Environmental Reviews, 24(2), 115-121. https://doi.org/10.1139/er-20150064.

13. Manzi, M., \& Coomes, O. T. (2002). Cormorant fishing in southwestern China: A traditional fishery under siege. Geographical Review, 92(4), 597-603. https://doi.org/10.1111/j.1931-0846.2002.tb00015.x.

14. Marine \& Fisheries Service of South Kalimantan Province. 2017. Annuity Report of Inland Fisheries in 2012 - 2016. [in Indonesian].

15. Monk, C. T., \& Arlinghaus, R. (2017). Encountering a bait is necessary but insufficient to explain individual variability in vulnerability to angling in two freshwater benthivorous fish in the wild. PLoS ONE, 12(3), 1-26. https://doi.org/10.1371/journal.pone.0173989.

16. Muhammad, H., lqbal, Z., \& Saleemi, S. (2016). Diversity and Distribution of Fish Fauna of Indus River at Taunsa Barrage in Punjab, Pakistan. Pakistan Journal of Zoology, 49(1), 149-154. https://doi.org/10.17582/journal.pjz/2017.49.1.149.154.

17. Muntaziana, M. P. A., Amin, S. M. N., Aminur Rah, M., Rahim, A. A., \& Marimuthu, K. (2013). Present Culture Status of the Endangered Snakehead, Channa striatus (Bloch, 1793). Asian Journal of Animal and Veterinary Advances, 8(2), 369-375. https://doi.org/10.3923/ajava.2013.369.375.

18. Ndobe, S., Serdiati, N., \& Moore, A. (2014). Domestication and Length-Weight Relationship of Striped Snakehead Channa striata (Bloch ). Proceedings of International Conference of Aquaculture Indonesia (ICAI), (2008), 165-172. Retrieved from http://epaper.aquaculture-mai.org/content/server/download.php.

19. Raby, G. D., Colotelo, A. H., Blouin-Demers, G., \& Cooke, S. J. (2011). Freshwater Commercial Bycatch: An Understated Conservation Problem. BioScience, 61(4), 271280. https://doi.org/10.1525/bio.2011.61.4.7.

20. Robert, R., Amit, N. H., Sukarno, N. M., Majapun, R. J., \& Kumar, S. V. (2019). Population genetic structure of Asian snakehead fish (Channa striata) in North Borneo: Implications for conservation of local freshwater biodiversity. Ecological Research, 34(1), 55-67. https://doi.org/10.1111/1440-1703.1008.

21. Sofia, L. A. (2017). Fishermen's perception and participation in fisheries resources conservation of batungap swamp in Tapin Regency, South Kalimantan, Indonesia. AACL Bioflux, 10(6), 1618-1626.

22. Sofia, L. A., \& Nurlianti, S. (2019). The economic value of the resource utilization of wetlands: Comparative study of beje fisheries in North Hulu, Sungai Regency, South Kalimantan, Indonesia. AACL Bioflux, 12(1), 143-150.

23. Sudirman. 2013. Developing tuna fishing business in the city of Sorong, West Papua. Airaha Journal. 2: 11-19. (in Indonesia).

24. Tan, M. P., Jamsari, A. F. J., \& Siti Azizah, M. N. (2012). Phylogeographic Pattern of the Striped Snakehead, Channa striata in Sundaland: Ancient River Connectivity, Geographical and Anthropogenic Singnatures. PLoS ONE, 7(12), 1-11. https://doi.org/10.1371/journal.pone.0052089. 